\begin{tabular}{|c|c|c|c|}
\hline Group & $\begin{array}{l}\text { Riboflavin in diet } \\
(\mu \mathrm{gm} . / \mathrm{gm} .)\end{array}$ & $\begin{array}{l}\text { Serum riboflavin } \\
(\mu \mathrm{gm} . / \mathrm{ml} .) \pm \delta\end{array}$ & $\begin{array}{l}\text { Riboflavin in eggs } \\
(\mu \mathrm{gm} . / \mathrm{gm} .) \pm \varepsilon\end{array}$ \\
\hline $\begin{array}{l}1 \\
2 \\
3\end{array}$ & $\begin{array}{l}1 \cdot 56 \\
3 \cdot 60 \\
5 \cdot 55\end{array}$ & $\begin{array}{l}0.285 \pm 0.03 \\
0 \cdot 778 \pm 0.07 \\
0.880 \pm 0.07\end{array}$ & $\begin{array}{l}2 \cdot 31 \pm 0.13 \\
4.18 \pm 0.22 \\
4.92 \pm 0.22\end{array}$ \\
\hline
\end{tabular}

Fluorimetric assays were carried out on the diets, blood sera and eggs by the method of Kodicek and Wang ${ }^{5}$. The accompanying table shows the results obtained.

It will be seen from these results that the serum riboflavin is substantially increased by supplementing the diet and that the blood-levels are directly related to egg content. An increase in the diet above $3.6 \mu \mathrm{gm}$. $\mathrm{gm}$. did not result in a significant increase in serum level ; this would appear to be in accordance with the observation of Petersen $e t a l .^{3}$ that further increase in hatchability from the inclusion of riboflavin in the diet is not attained beyond this dietary level for battery-kept birds.

Agricultural Chemistry Department, W. O. Brown

Queen's University, Belfast,

and

Ministry of Agriculture (N.I.). ${ }^{1}$ Lepovsky, S., Taylor. I. W., Jukes, T. H., and Almquist, H. J.,
Hilgardia, 11, 559 (1938).

${ }_{2}^{2}$ Engel, R. W., Phillips, P. H., and Halpin, J. G., Poult. Sci., 19. 135 (1940).

${ }^{3}$ Petersen, C. F., Lampman, C. E., and Stamberg, O. E., Poult. Sci., 26, 187 (1947),

+ Common, R. H., Rutledge, W. A., and Bolton, W., J. Endocrinol.,

${ }^{5}$ Kodicek, E., and Wang, Y. I., Biochem. J., 44,340 (1949).

\section{Production of Specific Group N Precipitating Sera for Streptococcus cremoris by 'Absorption' of Non-specific Antigens}

Due in part to the difficulty of preparing a specific group $N$ precipitating serum for Streptococcus cremoris, the boundaries and constituents of serological group $N$ have been so far incompletely determined. Although, by means of serological methods using interfacial precipitin tests with hydrochloric acid extracts, Str. cremoris has been grouped with Streptococcus lactis by Shattock and Mattick ${ }^{1}$, and with Str. lactis and with Streptococcus diacetilactis by Swartling ${ }^{2}$, final confirmation of its serological identity with group $N$ must depend on the preparation of a specific group serum for Str. cremoris itself.

Early attempts in this laboratory to produce such a serum in rabbits, using as vaccines living and variously heat- and chemically-treated bacterial cells, yielded only non-specific products, cross-reactions occurring most commonly and intensively with hydrochloric acid extracts of the streptococci of groups $K$ and $L$. Absorption of these non-specific sera with suspensions of $K$ and $L$ streptococci completely removed the non-specific antibodies and only partially impaired the group $N$ reactions. In order to produce a powerful serum specific in the first instance, it was clearly necessary to inactivate the non-specific antigens in the cremoris cells constituting the vaccine before the immunization process was begun. By 'absorbing' Str. cremoris cells with sera of groups $K$ and $L$, these antigens were eliminated or rendered non-antigenic, and specific group $N$ sera were obtained forthwith. Such sera have been prepared for both freeze-dried and freshly isolated strains of Str. cremoris.

The details of this work will be published elsewhere.

Department of Bacteriology

C. A. E. Briggs

National Institute for Research in Dairying, University of Reading.

$$
\text { Oct. } 31 .
$$

${ }^{1}$ Shattock, P. M. F., and Mattick, A. T. R., J. Hyg. Camb., 43, 173 (1943).

${ }^{2}$ Swartling, P. F., J. Dairy Res., 18, 256 (1951).

\section{Grana-like Structures of Synechococcus cedorum}

DuRING photosynthetic studies in this laboratory, the desire for an organism possessing a simple internal structure prompted us to investigate the blue-green algæ. It has occasionally been reported that these organisms contain grana or chloroplasts; but the most widely accepted opinion is that all their pigments are uniformly distributed throughout the cytoplasm ${ }^{1}$.

A pure culture of a unicellular blue-green alga, Synechococcus cedorum, was grown in an inorganie medium, and one-day old cells were used for investigating the pigment distribution. After the cells were harvested by centrifuging and washed with water, they were broken by grinding with alumina ${ }^{2}$. The mixture was diluted with water and centrifuged at $2,000 \mathrm{~g}$ for $10 \mathrm{~min}$. to remove unbroken cells, cell debris and alumina. A blue-green supernatant having a strong Tyndall effect and slight fluorescence was obtained. This supernatant was then centrifuged in a refrigerated Spinco ultracentrifuge for $30 \mathrm{~min}$. at $36,000 \mathrm{~g}$. A clear blue supernatant above a very minute green sediment was obtained. The absorption spectra of the intact cells and of the several fractions were determined from $3500 \mathrm{~A}$. to $7500 \mathrm{~A}$. with a Cary recording spectrophotometer. - The curves of the aqueous solutions or suspensions are shown in Fig. 1.

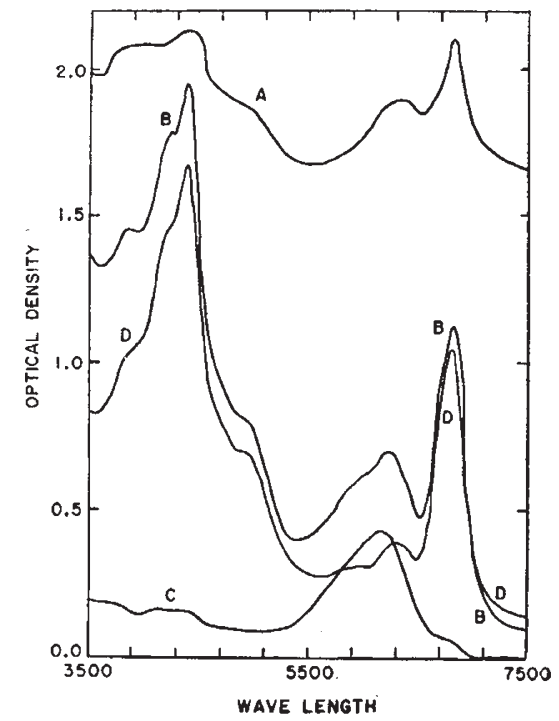

Fig. 1. Absorption spectra of Synechococcus cedorum. (A) Whole cells ; $(B)$ supernatant $(2,000 g)$ from alumina-treated cells ; i $(C)$, supernatant $(36,000 \mathrm{~g})$ after ultracentrifugation ; $(D) \mathrm{r}$ 